\title{
Van gedwongen ontslag naar het delen van de pijn
}

prof. Paul de Beer*

\section{Inleiding}

Een zelden opgemerkt raadsel van de arbeidsmarkt is dat er gedwongen ontslagen plaatsvinden als organisaties economische tegenwind ondervinden. We lijken het vanzelfsprekend te vinden dat een bedrijf dat geconfronteerd wordt met een forse terugval in de productie - bijvoorbeeld als gevolg van een economische recessie een deel van het personeel ontslaat. Maar zou het niet veel logischer zijn als bij een economische terugval het gehele personeel tijdelijk korter gaat werken en salaris inlevert, zodat gedwongen ontslagen kunnen worden voorkomen? Meer concreet, als de productie tien procent daalt, waarom wordt dan tien procent van het personeel ontslagen in plaats van dat alle medewerkers tien procent korter gaan werken en tien procent van hun salaris inleveren? Dit laatste is in de bestaande situatie meestal niet eenvoudig te realiseren, omdat de werkgever de arbeidsvoorwaarden niet eenzijdig kan wijzigen. De automatische aanpassing van de lonen in geval van een terugval in de productie zou echter wel onderdeel kunnen worden van cao-afspraken.

In dit artikel bespreek ik eerst waarom in de bestaande situatie gedwongen ontslagen veel gebruikelijker zijn dan het verdelen van de pijn. Vervolgens zet ik een alternatief systeem van loonvorming uiteen dat er juist op gericht is gedwongen ontslagen zo veel mogelijk te voorkomen, doordat de lonen meeademen met de toegevoegde waarde van een bedrijf. Daarna laat ik zien dat een structurele vorm van de huidige noodmaatregel NOW ertoe kan bijdragen dat zo'n alternatief systeem voor alle partijen aantrekkelijker wordt. Niettemin kan een aantal bezwaren tegen een dergelijk systeem worden geopperd, die ik echter zal proberen te weerleggen. Ik concludeer dan ook dat er veel voor te zeggen valt om de overgang naar een alternatief loonvormingssysteem en de invoering van een structurele NOW te overwegen. Ik benader dit alternatief voor gedwongen ontslagen primair vanuit een economisch perspectief en ga niet in op mogelijke juridische complicaties.

Paul de Beer is werkzaam als professor in arbeidsverhoudingen bij het AIAS-HSI.

\section{Waarom gedwongen ontslagen zo gebruikelijk zijn}

Waarom zijn in de bestaande situatie gedwongen ontslagen veel gebruikelijker dan het tijdelijk korter laten werken en minder laten verdienen van alle medewerkers? Voor het bedrijf zelf is het laatste antrekkelijker, omdat het ontslaan van personeel kosten met zich meebrengt (waaronder de verplichte transitievergoeding) en vaak ook onrust onder het personeel veroorzaakt. Als de vraag na verloop van tijd weer aantrekt, brengt het werven van nieuw personeel opnieuw kosten met zich mee. Voor de medewerkers die anders ontslagen zouden worden, is het meestal aantrekkelijker om tijdelijk korter te gaan werken. Dit is niet alleen zo omdat zij in geval van ontslag een forse inkomensachteruitgang ondervinden, maar ook omdat onvrijwillig ontslag en werkloosheid grote psychische en sociale kosten met zich meebrengen. Dit is voor het eerst vastgesteld in het klassieke onderzoek van Jahoda, Lazarsfeld en Zeisel ${ }^{1}$ naar massawerkloosheid in de jaren dertig van de vorige eeuw. In vele latere onderzoeken is hiervoor bevestiging gevonden. ${ }^{2}$ Het spreiden van de pijn is echter minder aantrekkelijk voor de medewerkers die anders niet zouden zijn ontslagen en weinig van de economische terugval zouden merken - behalve dan dat sommige van hun collega's gedwongen vertrekken. $\mathrm{Zij}$ zullen nu ook een tijdelijke inkomensachteruitgang ondervinden - al staat daar tegenover dat zij tijdelijk minder uren hoeven te werken. Doordat er bijna altijd meer medewerkers zijn die redelijk zeker zijn van hun baan dan collega's die ontslag wacht, heeft doorgaans een meerderheid van het personeel er geen belang bij dat iedereen meebetaalt aan het opvangen van de economische terugval. Alleen als er een faillissement dreigt, waardoor alle werknemers een vergelijkbaar risico op gedwongen ontslag lopen, verdwijnt deze tegenstelling tussen de minderheid en de meerderheid. Maar als dat faillissement onafwendbaar is, zal het inleveren van loon consequenties hebben voor de latere WW-aanspraken en dus evenmin aantrekkelijk zijn.

1. M. Jahoda, P.F. Lazarsfeld \& H. Zeisel, Die Arbeitslosen von Marienthal: ein soziographischer Versuch über die Wirkungen langandauernder Arbeitslosigkeit, mit einem Anhang zur Geschichte der Soziographie (Vol. 2). Verlag für Demoskopie (1960; oorspr. 1933).

2. Bijv. P. Warr, Work, unemployment, and mental health. Oxford University Press 1987; P. Ouweneel, 'Social Security and Well-being of the Unemployed in 42 nations', Journal of Happiness Studies 3, 2002, p. 167-192. 
Die meerderheid met weinig risico op ontslag omvat in het algemeen de medewerkers met de sterkste positie - een vast contract en een lang dienstverband - en hun belangen worden veelal ook het best vertegenwoordigd door de vakbonden. Bij een terugval in de activiteiten van een bedrijf worden immers doorgaans als eerste de contracten van medewerkers met een tijdelijk dienstverband niet verlengd. ${ }^{3}$ Deze werknemers zijn ook minder vaak lid van een vakbond dan werknemers met een contract voor onbepaalde tijd. ${ }^{4}$ Dit verklaart tevens waarom vakbonden maar zelden zelf voorstellen om ontslagen te voorkomen door tijdelijk voor iedereen de werktijd te verkorten.

Er is nog een andere reden waarom het verdelen van de pijn minder aantrekkelijk is dan het afwentelen ervan op een deel van het personeel door ontslag. Gedwongen ontslag wordt feitelijk gesubsidieerd door de overheid. Immers, wie ontslagen wordt heeft in beginsel recht op een WW-uitkering van aanvankelijk $75 \%$ en na twee maanden $70 \%$ van het laatst verdiende loon. Een groot deel van het inkomensverlies van de ontslagen werknemers wordt dus gecompenseerd. Dit geldt echter niet voor het inkomensverlies dat de werknemers lijden als zij allemaal korter gaan werken en daarvoor salaris inleveren. Het gezamenlijke inkomensoffer dat de werknemers brengen als zij korter gaan werken is dus ruwweg viermaal zo groot als het inkomensoffer van de werknemers die anders zouden worden ontslagen (namelijk $100 \%$ ten opzichte van aanvankelijk $25 \%$ en later $30 \%$ voor medewerkers die werkloos worden). Zo bezien werkt de WW-uitkering als een 'bonus' voor het ontslaan van personeel in plaats van het in dienst te houden van alle medewerkers voor een kortere werktijd.

\section{Een alternatief loonvormingssysteem}

Het gevolg van dit alles is dat een economische crisis op de arbeidsmarkt vooral doorwerkt in de vorm van volume-aanpassingen en veel minder in de vorm van prijsaanpassingen. Anders gezegd: het aantal werknemers neemt af in een recessie, maar de lonen reageren maar zwak en met vertraging op een conjuncturele terugval. Deze constatering was in 1984 aanleiding voor de Amerikaanse econoom Martin L. Weitzman om in zijn boek The Share Economy voor een heel ander systeem van loonvorming te pleiten. ${ }^{5}$ Het boek trok destijds veel aandacht en lokte veel discussie uit, maar bijna veertig jaar later lijkt het grotendeels vergeten. Dat is jammer, want

3. Zie bijv. SCP, Kwetsbare groepen op de arbeidsmarkt. Beleidssignalement maatschappelijke gevolgen coronamaatregelen, Den Haag: Sociaal en Cultureel Planbureau 2020.

4. Volgens de Nederlandse Enquête Arbeidsomstandigheden (NEA) van TNO en CBS was in 2018 21\% van de werknemers met een vast dienstverband lid van een vakbond en $9 \%$ van de werknemers met een flexibel dienstverband.

5. M.L. Weitzman, The Share Economy. Conquering stagflation. Cambridge (Mass.): Harvard University Press 1984 zijn analyse heeft weinig aan actualiteit verloren en zou ook in deze tijd, waarin we alweer de vierde recessie hebben meegemaakt sinds hij het boek schreef, een belangrijke inspiratiebron kunnen zijn.

Martin Weitzman stelde in zijn boek een radicaal ander mechanisme voor de loonvorming voor. Waar nu de lonen relatief star zijn en de werkgelegenheid meebeweegt met de omzet van een bedrijf, stelde hij voor om de lonen juist mee te laten ademen met de omzet, waardoor de werkgelegenheid relatief stabiel blijft. Dit zou kunnen worden gerealiseerd door in onderhandelingen tussen vakbonden en werkgever te bepalen dat de totale loonsom van het bedrijf een vast deel van de totale toegevoegde waarde van de onderneming is. ${ }^{6}$ De toegevoegde waarde is wat een bedrijf netto verdient, dat wil zeggen de optelsom van de lonen van zijn medewerkers en de beloning van de aandeelhouders, oftewel de winst. De loonsom zal zich in dat geval automatisch aanpassen aan veranderingen in de toegevoegde waarde. Simpel gezegd, als de toegevoegde waarde met tien procent afneemt, dalen ook de winst en de loonsom met tien procent. In de bestaande situatie, met 'starre' lonen, blijft de loonsom in eerste instantie gelijk en wordt de daling van de toegevoegde waarde volledig opgevangen door de winst, die dan veel sterker daalt. (Om de gedachten te bepalen: als de loonsom twee derde van de toegevoegde waarde bedraagt en gelijk blijft, zal de winst met dertig procent dalen als de toegevoegde waarde met tien procent daalt.) Die sterke winstdaling is een belangrijke reden voor het management om personeel te ontslaan en daarmee de loonsom te verminderen, zodat de winst minder sterk wordt aangetast. Als tien procent van het personeel wordt ontslagen, daalt de loonsom met tien procent en zal ook de winst met slechts tien procent dalen.

Een bedrijf waarvan de loonsom automatisch daalt als de toegevoegde waarde afneemt, zal veel minder snel besluiten om personeel te ontslaan. De loonsom neemt daardoor immers niet verder af, maar wel maakt het bedrijf kosten om het ontslag te realiseren (zoals een ontslagvergoeding). Als het bedrijf niemand ontslaat, gaat het loon van het gehele personeel automatisch tien procent omlaag, maar hoeft niemand bang te zijn om haar/zijn baan kwijt te raken.

\section{Hoe een deelsysteem voor alle partijen aantrekkelijker kan worden}

Vakbonden zijn in het algemeen geen voorstander van een systeem waarin de lonen automatisch 'meeademen', zoals bleek toen werkgeversvereniging AWVN in 2020

6. Volgens Weitzman kan de loonsom ook aan een andere indicator worden gekoppeld, zoals de omzet of de cashflow. 
een dergelijk systeem voorstelde. ${ }^{7}$ Een veel gehoord bezwaar van vakbondskant is dat werknemers hiermee gaan meedelen in het ondernemingsrisico. Dat is op zichzelf juist, maar het suggereert dat dit in de huidige situatie niet het geval zou zijn, terwijl de medewerkers die worden ontslagen natuurlijk dubbel en dwars meedelen in het ondernemingsrisico. Dat meedelen in het ondernemingsrisico door het gehele personeel heeft bovendien ook een zonnige zijde: als de vraag weer aantrekt en de toegevoegde waarde van het bedrijf weer groeit, stijgen de lonen (of in ieder geval de loonsom) automatisch mee. Dat is echter iets waar de vakbonden vaak minder gerust op zijn: als de werknemers loon inleveren in economisch slechte tijden, hoe zeker zijn zij dan dat zij in goede tijden meeprofiteren van het herstel? Dat lijkt immers in de periode van hoogconjunctuur voorafgaand aan de coronacrisis nauwelijks het geval te zijn geweest.

Als vakbonden en werkgever(s) hierover voor een langere periode bindende afspraken maken en een deelsysteem dus een structureel karakter krijgt, zal dit op langere termijn echter niet gepaard gaan met grotere inkomensrisico's voor de medewerkers, terwijl hun werkzekerheid wel groter wordt. In economisch slechte tijden zullen de lonen eerder en sneller dalen, maar bij economisch herstel zullen zij ook weer eerder en sterker stijgen. Bovendien geldt dat degenen die nu in een recessie worden ontslagen meestal niet meedelen in de groei als de economie weer aantrekt, omdat zij veelal niet door hetzelfde bedrijf dat hen eerder heeft ontslagen, weer worden aangenomen.

Zelfs als vakbonden in beginsel positief zouden staan tegenover een deelsysteem, blijft het nadeel ervan dat de werknemers gezamenlijk de 'overheidssubsidie' voor ontslag in de vorm van de WW-uitkering zullen missen. Voor alle werknemers tezamen (inclusief degenen die nu in een recessie worden ontslagen) zullen de schommelingen in het inkomen dan toch groter zijn dan nu het geval is. De oplossing voor dit probleem zou kunnen zijn dat de overheid, naast de WW-uitkering, een preventief instrument inzet om loonaanpassingen te compenseren en daarmee ontslagen te voorkomen. Dit lijkt veel op wat de Nederlandse overheid gedurende de coronacrisis heeft gedaan in de vorm van de NOW, de tijdelijke Noodmaatregel Overbrugging voor Werkgelegenheid.

De NOW bood aan werkgevers een tegemoetkoming in de loonkosten als hun omzet als gevolg van de coronacrisis was teruggevallen. Die tegemoetkoming bedroeg aanvankelijk (bij de NOW-1) 90\% van de loonkosten voor het percentage dat de omzet was afgenomen. Later werd dit verlaagd tot $80 \%$ en daarna weer verhoogd naar $85 \%$. Daarbovenop kregen de bedrijven een tegemoetkoming voor de vaste lasten. Feitelijk komt de NOW-regeling erop neer dat de overheid, in plaats van een uitkering te verstrekken na ontslag, gedwongen ont- slagen probeert te voorkomen door aan bedrijven een subsidie te verstrekken voor de uren dat werknemers minder gaan werken als gevolg van het omzetverlies van de onderneming. Opmerkelijk is dat de vergoeding die de NOW biedt voor dit urenverlies zelfs hoger is dan de WW-uitkering. Op grond van eerste analyses van het Centraal Planbureau ${ }^{8}$ lijkt de NOW zeer effectief te zijn geweest in het voorkomen van gedwongen ontslagen. De werkloosheid is tijdens de coronacrisis dan ook veel minder sterk toegenomen dan op grond van de economische terugval te verwachten was.

$\mathrm{Nu}$ was de NOW een tijdelijke noodmaatregel die weer gestopt is nu de coronacrisis voorbij lijkt te zijn. In het licht van bovenstaande beschouwing en de analyse van Weitzman is er echter alle reden om de NOW een meer structureel karakter te geven. Dit zou betekenen dat overheidssteun voor behoud van werkgelegenheid niet langer een buitengewone maatregel is voor een uitzonderlijke situatie, maar een regulier instrument om te bevorderen dat de werkgelegenheid minder sterk fluctueert met de conjunctuur.

Meer concreet zou een structurele NOW-regeling kunnen inhouden dat een onderneming of instelling die een forse terugval in de omzet ondervindt (bijv. minimaal met $20 \%$, zoals bij de NOW als voorwaarde gold) en als reactie daarop de medewerkers tijdelijk korter laat werken, een tegemoetkoming ontvangt van bijvoorbeeld $75 \%$ of $70 \%$ (overeenkomstig de hoogte van de WWuitkering) van de loonkosten voor de uren dat er niet wordt gewerkt. Omdat deze regeling alleen is bedoeld voor een tijdelijke terugval in de omzet, zou de duur van de tegemoetkoming beperkt moeten zijn. Daarmee wordt voorkomen dat bedrijven die in structurele problemen verkeren en de personeelsomvang permanent moeten reduceren structureel gesubsidieerd zouden worden en zo kunstmatig in leven worden gehouden. Te overwegen valt om de tegemoetkoming stapsgewijs te verlagen, zodat de prikkel geleidelijk toeneemt om, indien de terugval niet tijdelijk is, meer structurele maatregelen te nemen. De werknemers zullen dan permanent een lager loon moeten accepteren of het bedrijf zal toch personeel moeten ontslaan. De meeste bedrijven, die alleen te kampen hebben met een conjuncturele inzinking, zullen echter weer naar hun oude productieen loonniveau kunnen terugkeren.

Een structurele NOW-regeling laat de vraag open in welke mate de lonen moeten worden aangepast als de omzet van een bedrijf terugvalt. Als de tegemoetkoming aan de werkgever wordt uitbetaald en daarmee een groot deel van de niet-gewerkte uren compenseert, is er minder noodzaak om ook de lonen te verlagen. Niettemin zouden vakbonden en werkgevers met elkaar kunnen afspreken hoe de $25 \%$ kosten van het urenverlies waarvoor geen compensatie wordt geboden, wordt verdeeld tussen de onderneming en het personeel. Terugkomend op de redenering waarmee dit artikel begon, heeft deze 
structurele NOW-regeling het voordeel dat de omvang van de overheidssubsidie in beginsel gelijk is wanneer er ontslagen vallen en wanneer alle werknemers korter gaan werken. Ervan uitgaande dat gedwongen ontslag voor zowel de werkgever als de ontslagen werknemers extra kosten met zich meebrengt, naast het inkomensverlies, zou het daarmee financieel veel aantrekkelijker worden om het omzetverlies op te vangen door alle medewerkers tijdelijk korter te laten werken en daarvoor eventueel in beperkte mate loon in te leveren.

Het is ook denkbaar om de structurele NOW-tegemoetkoming niet aan de werkgever ten goede te laten komen, maar aan de werknemers. De tegemoetkoming zou dan voorwaardelijk kunnen zijn op een tijdelijke verlaging van het loon in een crisissituatie. Als het loon bijvoorbeeld $10 \%$ daalt, zou driekwart daarvan gecompenseerd kunnen worden door de overheid. In dit geval zou de regeling een directe stimulans zijn voor een deelsysteem zoals voorgesteld door Weitzman. De fluctuatie in het loon van de werknemers, die vakbonden als een bezwaar zien tegen een dergelijk systeem, zou hierdoor aanzienlijk worden gematigd.

\section{Bezwaren tegen een deelsysteem gewogen en te licht bevonden}

Een deelsysteem in combinatie met een structurele tegemoetkoming door de overheid om het inkomensverlies te compenseren, zou niettemin op een aantal bezwaren kunnen stuiten. ${ }^{9}$

Een eerste voor de hand liggend bezwaar is dat dit de overheid op hoge kosten zou jagen, omdat zij bij iedere forse terugval in de omzet van bedrijven subsidie zou moeten verstrekken. Hier staat tegenover dat naar verwachting aanzienlijk minder $\mathrm{WW}$-uitkeringen hoeven te worden uitbetaald, omdat veel minder werknemers worden ontslagen. Uit onderzoek is bovendien bekend dat werkloosheid, als deze langer dan ruwweg een halfjaar duurt, al snel een zichzelf versterkend effect krijgt (economen noemen dit hysterese), omdat werklozen minder 'werkfit' worden (door verlies aan werkritme en veroudering van kwalificaties) en langdurige werkloosheid stigmatiserend werkt, waardoor werkgevers liever geen langdurig werklozen aannemen. Als het aantal gedwongen ontslagen sterk wordt gereduceerd zullen er op termijn ook aanzienlijk minder langdurig werklozen zijn, en daarmee kunnen extra besparingen op de WW worden gerealiseerd. (Dit positieve effect wordt wel kleiner naarmate de maximale duur van de WW-uitkering korter wordt, zoals sommige politieke partijen en ook de Commissie-Borstlap bepleiten.)
Een tweede bezwaar, dat vooral door economen naar voren wordt gebracht, is dat de mobiliteit op de arbeidsmarkt zal afnemen en er minder structurele aanpassingen in bedrijven zullen plaatsvinden, hetgeen nodig zou zijn voor een gezonde economische ontwikkeling. Deze waarschuwing werd ook door het Centraal Planbureau gegeven ten aanzien van de NOW-regeling. ${ }^{10}$ Als bedrijven dankzij overheidssteun te lang wachten met reorganisaties en ontslagen op den duur onvermijdelijk zijn, zou dit het aanpassingsvermogen van de economie kunnen schaden. Als er voor werknemers op langere termijn geen perspectief is op werk in hun huidige bedrijf, zou het beter zijn als zij zo snel mogelijk op zoek gaan naar een 'functie elders' die meer toekomstperspectief biedt. Tegen dit bezwaar valt echter wel wat in te brengen. Juist in een crisissituatie is het voor werknemers die ontslagen worden vaak moeilijk om snel elders een goede andere functie te vinden. $\mathrm{Zij}$ lopen dan ofwel het risico langdurig werkloos te blijven - met de negatieve gevolgen die ik hierboven signaleerde - ofwel moeten zij een baan aanvaarden die slecht aansluit bij hun kennis en vaardigheden, waardoor hun capaciteiten worden onderbenut. Ook in het laatste geval is het vaak niet gemakkelijk later naar een betere baan over te stappen, omdat werkgevers bij het werven van personeel vaak vooral naar de meest recente werkervaring kijken.

Daar staat tegenover dat een deelsysteem structurele aanpassingen niet per se in de weg staat. Stel dat de loonsom van een bedrijf is gekoppeld aan de toegevoegde waarde en die toegevoegde waarde loopt structureel terug, bijvoorbeeld doordat het bedrijf in een krimpende markt opereert of het marktaandeel steeds kleiner wordt. In dat geval zal het loon van de werknemers, zolang er geen ontslagen vallen, structureel dalen, waardoor de arbeidsvoorwaarden steeds slechter worden in vergelijking met de concurrenten. De kans is dan groot dat steeds meer medewerkers op zoek gaan naar een beter betaalde baan elders. Het bedrijf zal steeds meer moeite hebben om de ontstane vacatures te vervullen, waardoor het op den duur in zijn voortbestaan wordt bedreigd, simpelweg door een tekort aan gekwalificeerd en gemotiveerd personeel. Waar het bestaande systeem van loonvorming in geval van een economische terugval vaak leidt tot een 'koude sanering' en gedwongen ontslagen, zal er in een deelsysteem eerder sprake zijn van een 'warme sanering' via vrijwillig vertrek van medewerkers. Zo'n 'warme sanering' is uit sociaal en economisch oogpunt veel aantrekkelijker, omdat werknemers alleen zullen vertrekken als zij ander werk hebben gevonden en er dus minder risico is op verlies aan productief vermogen en een beroep op de sociale verzekeringen.

Een derde mogelijk bezwaar tegen een deelsysteem is dat het een conservatieve opstelling van werknemers zou aanmoedigen. Immers, als de loonsom niet afhankelijk is van het aantal werknemers, maar alleen van de toegevoegde waarde van de onderneming, hebben de zittende 
werknemers er ogenschijnlijk belang bij dat er zo weinig mogelijk nieuwe medewerkers worden aangenomen. Meer werknemers maken de spoeling dun. Werknemers zouden zich dus kunnen verzetten tegen groei van de onderneming. Dit bezwaar is echter alleen reëel als er nieuw personeel zou worden aangenomen zonder dat de toegevoegde waarde van de onderneming groeit. Dit is niet erg aannemelijk, want een werkgever zal doorgaans alleen extra personeel aantrekken als er meer werk te doen valt en de omzet groeit. En zelfs als de groei van het personeel groter is dan de toename van de toegevoegde waarde hebben de zittende werknemers het voordeel dat dit in beginsel samengaat met vermindering van de werktijd of de werkdruk, omdat er dan meer handen beschikbaar zijn voor het werk dat moet worden gedaan.

Een vierde bezwaar dat tegen Weitzmans deelsysteem is geopperd, is dat het een rem zou zetten op investeringen en innovatie. Immers, in een deelsysteem delen de werknemers automatisch mee als de toegevoegde waarde en daarmee de winst van een onderneming stijgen. Dit betekent dat in een groeiend bedrijf de winst minder snel toeneemt dan wanneer de lonen niet automatisch meegroeien met de toegevoegde waarde. De kapitaalverstrekkers (de aandeelhouders) hebben dan minder belang bij investeringen omdat de opbrengst van die investeringen ten dele zal toevallen aan de werknemers. Dit kan innovatie remmen. Ook tegen dit bezwaar valt echter het een en ander in te brengen. Ook als er geen sprake is van een deelsysteem zullen vakbonden doorgaans proberen een deel van de winst op te eisen als de toegevoegde waarde stijgt. Het belangrijkste verschil is dat dit in een deelsysteem automatisch en daardoor sneller verloopt. In het bestaande systeem van loonvorming lopen de lonen vaak twee tot drie jaar achter op de economische conjunctuur: als er een recessie intreedt, duurt het geruime tijd voordat de lonen neerwaarts worden aangepast en in de opgaande fase neemt het ook de nodige tijd voor de lonen weer sneller stijgen. Het belangrijkste effect van een deelsysteem is dat deze loonaanpassingen naar voren worden gehaald, waardoor ze nauwer aansluiten bij de economische golfbeweging. Dit zal in beginsel niet van invloed zijn op de structurele, trendmatige loonontwikkeling op langere termijn en dus ook niet op de verdeling van de toegevoegde waarde over lonen en winst. Op langere termijn neemt het rendement op investeringen dan ook niet af.

Hier komt bij dat veel onderzoek laat zien dat een systeem van winstdeling - wat het deelsysteem feitelijk ook is - kan bijdragen aan de betrokkenheid van werknemers. ${ }^{11}$ Als medewerkers weten dat zij automatisch meedelen in een stijging van de winst, hebben zij er ook meer belang bij om zich maximaal voor de onderneming in te zetten en bijvoorbeeld suggesties te doen om het productieproces efficiënter te maken. Uiteindelijk kunnen daar zowel de werknemers als de aandeelhouders van profiteren, omdat het bijdraagt aan vergroting van de toegevoegde waarde, zodat er ook meer te delen valt.

\section{Tot besluit}

Ik concludeer dat een deelsysteem dat ondersteund wordt door een structurele NOW-regeling een veelbelovend en aantrekkelijk alternatief is voor het bestaande systeem van loonvorming en aanpassing van de werkgelegenheid. Het zou betekenen dat de pijn van een economische crisis veel gelijkmatiger verdeeld wordt over alle werkenden. Volume-aanpassingen (meer of minder personeel) worden grotendeels vervangen door prijsaanpassingen (meer of minder loon), die voor een belangrijk deel worden gecompenseerd door de overheid via een structurele NOW-regeling. Het effect zal zijn dat tijdens een economische crisis aanzienlijk minder werknemers worden ontslagen, maar dat de zittende werknemers tijdelijk korter gaan werken en iets minder gaan verdienen. Omgekeerd zal in een aantrekkende economie natuurlijk ook het aantal medewerkers dat wordt aangenomen, kleiner zijn en zullen de zittende werknemers dan weer meer uren gaan werken en meer verdienen. Omdat onvrijwillige werkloosheid maatschappelijk gezien een kostbaar fenomeen is, zal deze overgang niet alleen leiden tot een meer gelijkmatige spreiding van de 'pijn' in tijden van crisis, maar ook tot minder verspilling van talent en productief vermogen. Uiteindelijk is iedereen daardoor beter af.

Omdat een deelsysteem voor veel werknemers - en daardoor ook voor vakbonden - minder aantrekkelijk is dan de bestaande situatie, is het essentieel dat de overheid de invoering van een dergelijk systeem ondersteunt met een inkomenscompensatie in de vorm van een structurele NOW-regeling. Terwijl de WW alleen compensatie biedt aan ontslagen werknemers, zou de overheid daarmee preventief - zoals tijdens de coronacrisis optreden om gedwongen ontslagen zo veel mogelijk te voorkomen en voor alle werknemers meer baan- en werkzekerheid te creëren. 